\title{
Performance Based Pay Management as a Determinant of Procedural Justice
}

\author{
Mohd Ridwan Abd Razak ${ }^{1}$, Azman Ismail ${ }^{2}$ \& Enah Ali ${ }^{3}$ \\ 1,2Universiti Kebangsaan Malaysia, ${ }^{3}$ Universiti Pendidikan Sultan Idris \\ mohdridwan76@gmail.com ${ }^{1}$,azisma08@gmail.com²,edwan01@yahoo.com.my ${ }^{3}$
}

DOI: https://doi.org/10.37134/jcit.vol8.3.2018

\begin{abstract}
The main objective of this study is to examine the relationship between performance based pay management (i.e., communication and participation) and procedural justice. A survey methods were used to collect selfreport survey of employees in currier service company. The SmartPLS path model analysis revealed two main findings: first, communication was significantly correlated with procedural justice. Second, participation was significantly correlated with procedural justice. These findings demonstrate that the ability of managers to properly implement performance based pay management may invoke feelings of procedural justice among employees in the organization. This study provides three important implications: first, this study may serve great potential for understanding the effect of communication and, participation in strengthening perception of procedural justice among employees in the organization. Second, the survey questionnaire used in this study had satisfactorily met the standards of validity and reliability analyses. This may lead to produced accurate and reliable research findings. Third, this study may serve as a guide for practitioners to enhance the effectiveness of organization's performance based pay management as an important instrument to motivate employee in supporting organization's pay system, objectives and strategies. In addition, discussion, implications and conclusion are described.
\end{abstract}

Keywords: Performance based reward management, communication, participation, procedural justice

\section{INTRODUCTION}

There is a growing body of literature that recognizes the importance of performance based pay management in addressing the issue of employee's justice since it may attract and retain competent employees to improve efficiency and productivity of the organization (Brebels, Cremer \& Dijke, 2016; Proost, 2015). There is evidence that performance based pay may enhance feeling of justice among employees and motivate employees to become more productive. For examples, research conducted by Research Institute of Economy, Trade \& Industry, Japan, revealed that adoption of performance based pay among Japanese companies show a significant increase of $30 \%$ since 2000. It is interesting that the implementation of performance based pay has increased the productivity of employees between $26 \%$ to $30 \%$ (Takao and Kodaman, 2015). This practice is related to performance measures as a way of absorbing increased labour costs, while at the same time rewarding and motivating employees.

An analysis of recent literature about pay system highlights that there are two categories of pay. Those are, pay for group performance (team based pay and gain sharing) and pay for individual performance (e.g., merit pay, lump sum bonus, promotion based incentives and variable pay) (Azman \& Mohd Ridwan, 2017a; Ismail \& Razak, 2016). Even though there are various categories of pay systems, they use similar principle to distribute 
pay (i.e., employees' performance, skills, knowledge and/or competency) and not by the nature of their job structure (Azman \& Mohd Ridwan, 2017b; Martocchio, 2016; Newman, Gerhart \& Milkovich, 2017).

Development of organizational pay system can be separated into two main approaches; those are conventional and contemporary approaches (Azman \& Mohd Ridwan, 2017b; Newman et al., 2017). According to the conventional approach, allocation of pay is based on job structure (e.g., seniority, length of service and classification of work) (Azman, Fuad \& Aimi, 2015; Azman, Ridwan \& Zalina, 2016b). Meanwhile, for contemporary approach, pay allocation is based on skills and knowledge, performance and productivity shown by employees in performing daily tasks (Azman \& Mohd Ridwan, 2017b; Osterloh, 2014). Pay allocation in this approach may increase the level of organization's competitiveness in the global market (Auh \& Menguc, 2013; Rozila \& Scott, 2015).

Implementation of performance based pay can be realized through the effective performance based pay management strategy. Performance based pay management is normally described as a procedure of allocating pay in a systematic method, based on employees' knowledge, skill, and/or performance (Newman et al., 2017; Osterloh, 2014; Webb et al., 2014). The management of performance based pay has two main components: communication, and participation (Aimi, Azman \& Fatmawati, 2014; Azman \& Mohd Ridwan, 2017b). Communication is generally defined as distributing the information about performance based pay systems from an employer to the employees (Martocchio, 2016; Milkovich, Newman \& Gerhart, 2014; Newman et al., 2017). Meanwhile, participation is frequently understood as the involvement of employees in decision-making activities, information-processing and/or problem-solving activities relating to the implementation of performance based pay systems (Salim \& Ismail, 2015; Shaed, Ishak \& Ramli, 2015). This situation shows that the ability of managers to properly apply communication openness and strongly inspire employee participation may enhance organizational productivity (Martocchio, 2016; Newman et al., 2017).

This situation is very interesting when the current studies highlights that the ability of managers to properly apply communication openness and strongly inspire employee participation in pay management systems may have a significant impact on personal outcomes, especially procedural justice (Dar \& Raja, 2014; Risher, 2014). In the organizations' pay management systems, procedural justice is usually interpreted as a perception of fairness about the process and methods used by managers in determining employees' pays. If employees perceived that the methods (e.g., policies, rules and regulations) that are used to determine their pay are consistent, accurate, ethical and fair, this feeling may lead to greater feeling of procedural justice among employees in organizations (Azman \& Mohd Ridwan, 2017b; Tremblay \& Landreville, 2015).

Within a performance based pay model, many researchers believed that communication, participation, performance appraisal and procedural justice are different constructs, but extremely interrelated. For instance, the ability of managers to professionally manage organizations' performance based pay system (i.e., communication, participation and performance appraisal) may enhance feeling of procedural justice in the organization (Azman, Asilah \& Rahamad, 2016a; Azman \& Mohd Ridwan, 2017a; Zhang, Long \& Zhang, 2015). Although the nature of this relationship is important, little is recognized about the role of performance based pay management as an important 
determinant of procedural justice in the organizational pay system research literature. Therefore, it strongly motivates the researchers to further discover the nature of this relationship.

\section{PURPOSE OF THE STUDY}

This study has two important objectives: first, to examine the relationship between communication and procedural justice. Second, to examine the relationship between participation and procedural justice.

\section{LITERATURE REVIEW}

\subsection{Relationship between communication and procedural justice}

Biddle's (1986), role theory describes that distribution of pay is an important sign of the high quality relationship between managers and employees and this situation may influent employees' positive behaviour in the organization. This idea received strong support from the performance based pay management research literature. For instance, several recent studies were conducted using a direct effects model to study communication based on different samples, such as perceptions of 236 supervisor from nine organizations in China (Zhang et al., 2015), 99 workers at public higher education institution in Peninsular Malaysia (Azman et al., 2016a) and 187 employees from three companies in Ireland (Heffernan \& Dundon, 2016). The findings of these studies found that the capability of managers to openly communicate the information about performance based pay (e.g., explanations, sharing information and negotiation) had enhanced procedural justice in the organizations (Azman et al., 2016a; Heffernan \& Dundon, 2016; Zhang et al., 2015). Thus, is was hypothesized that:

H1: Communication positively related to procedural justice

\subsection{Relationship between participation and procedural justice}

Graen and Uhl-Bein (1995) leader-member exchange theory suggest that that in-kind exchanges (e.g., morale and/or material) are a symbol of the high quality relationship between managers and employees and this practice may invoke employees' positive actions. This idea is in line with the performance based pay management research literature. For example, several studies that using a direct effect model to examine the relationship between participation and procedural justice using different sample, such as 159 employees of disaster agency in Malaysia (Azman \& Ridwan, 2017a), 370 employees from 60 Islamic microfinance institution in Indonesia (Wahibur \& Arif, 2012) and 187 employees from three companies in Ireland (Heffernan \& Dundon, 2016). The outcomes of these studies found that the capability of managers to actively inspire employees to involve in performance based pay (e.g., suggestion and decision making) may induce feeling of procedural justice among employees in the organization (Azman \& Mohd Ridwan, 2017a; Heffernan \& Dundon, 2016; Wahibur \& Arif, 2012). Thus, is was hypothesized that: 
H2: Participation positively related to procedural justice

\section{METHODOLOGY}

\subsection{Research Design}

This study employed a cross-sectional research design which allowed the researchers to integrate the performance based pay literature and the actual survey as a means to collect data for this study. Using this data collection procedure will help the researchers gather accurate data, decrease bias and increase quality of data being collected (Cresswell, 1998; Sekaran \& Bougie, 2010). This study was conducted at courier service company in Peninsular Malaysia. At the early stage of this study, a survey questionnaire was drafted based on the performance based pay literature. Then, a back translation technique was employed to translate the survey questionnaires into English and Malay versions in order to increase the validity and reliability of research findings (Cresswell, 1998; Sekaran \& Bougie, 2010).

\subsection{Measures}

The survey questionnaire consists of three parts: first, communication had 9 items adapted from the pay communication literature (Aimi et al., 2014; Newman et al., 2017; Singh \& Rana, 2015). Second, participation had 10 items adapted from the performance based pay literature (Azman et al., 2015; Ismail et al., 2011; Zhang, Lee \& Zou, 2010). Finally, procedural justice had 6 items adapted from the organizational justice literature (Ismail, Rahman \& Ismail, 2007; Zhang et al., 2015; Zou, Zhang \& Liu, 2015). All these items were measured using a 7-item scale ranging from "strongly disagree/dissatisfied" (1) to "strongly agree/satisfied" (7). Demographic variables were used as controlling variables because this study emphasized on employee attitudes.

\subsection{Sample}

This study employed a convenient sampling technique to collect 100 usable survey questionnaires from the employees who work at different job categories and levels in the organization. This sampling technique was applied because the management of the organization had not given the list of registered employees to the researchers and this situation did not allow the researchers to use a random technique in choosing respondents for this study. The survey questionnaires were answered by participants based on their consent and on a voluntary basis.

\subsection{Data Analysis}

The SmartPLS was used to assess the validity and reliability of the instrument and test the research hypotheses. The main advantages of using this method may deliver latent variable scores, avoid small sample size problems, estimate every complex model with many latent and manifest variables, hassle stringent assumptions about the distribution of variables and error terms, and handle both reflective and formative measurement models (Henseler, 2012; Ringle, Sarstedt \& Straub, 2012). The SmartPLS path model was employed to assess the path coefficients for the structural model using the standardized beta $(\beta)$ and $t$ statistics. 
The value of $\mathrm{R}^{2}$ is used as an indicator of the overall predictive strength of the model. The value of $\mathrm{R}^{2}$ is considered as follows: 0.19 (weak), 0.33 (moderate) and 0.67 (substantial) (Henseler, 2012; Henseler \& Chin, 2010). As an additional assessment of model fit in PLS analysis, we carried out a test of predictive relevance using blindfolding ( $\mathrm{Q}^{2}$ statistic) as suggested by Geisser (1975) and Stone (1974). According to Henseler and Chin (2010), the $\mathrm{Q}^{2}$ statistic is a jackknife version of the $\mathrm{R}^{2}$ statistic. It represents a measure of how well observed values are reconstructed by the model and its parameter estimates. Models with $\mathrm{Q}^{2}$ greater than zero are considered to have predictive relevance. The value of $\mathrm{Q}^{2}$ is considered as follows: 0.02 (small predictive relevance for an endogenous construct), 0.15 (medium predictive relevance for an endogenous construct), and 0.35 (large predictive relevance for an endogenous construct) (Hair, Hult, Ringle \& Sarstedt, 2017).

\section{FINDINGS}

From the sample profile, the majority of respondents were males (88\%), age from 35 to 44 years old (42\%), Malaysia Certificate of Education holders $(76 \%)$, work at branch office $(90 \%)$, working experience less than 5 years $(29 \%)$, permanent staff $(99 \%)$, monthly salary less than RM2000 (34\%), and married employees (73\%).

Table 1 shows the factor loadings and cross loadings for different constructs. The correlation between items and factors had higher loadings than other items in the different concepts, as well as the loadings of variables were greater than 0.70 in their own constructs in the model are considered adequate (Henseler \& Chin, 2010). Overall, the validity of the measurement model met the criteria. The values of composite reliability for all constructs were greater than 0.80 , indicating that the instrument used in this study had high internal consistency (Henseler \& Chin, 2010; Nunnally \& Bernstein, 1994).

Table 1. The Results of Factor Loadings and Cross Loadings for Different Constructs and Composite Reliability

\begin{tabular}{cccccc}
\hline \multirow{2}{*}{ Construct } & No. of & \multicolumn{3}{c}{ Cross Factor Loading } & Composite \\
\cline { 3 - 5 } & Item & 1 & 2 & 3 & Reliability \\
\hline Communication & 9 & 0.725 to 0.809 & & & 0.930 \\
Participation & 10 & & 0.737 to 0.877 & & 0.956 \\
Procedural & 6 & & & 0.821 to 0.907 & 0.943 \\
Justice & & & & \\
\hline
\end{tabular}

Table 2 shows the results of convergent and discriminant validity analysis. All constructs had the values of AVE larger than 0.5, indicating that they had met the acceptable standard of convergent validity (Barclay, Higgins \& Thompson, 1995; Fornell \& Larcker, 1981; Henseler, Ringle \& Sarstedt, 2014). In addition, Besides that, the values of all concepts' AVE in diagonal were greater than the squared correlation with other concepts in off diagonal, signifying that all concepts had met the acceptable standard of discriminant validity (Henseler and Chin, 2010). 
Table 2. The Results of Convergent and Discriminant Validity Analysis

\begin{tabular}{ccccc}
\hline Construct & AVE & Communication & Participation & $\begin{array}{c}\text { Procedural } \\
\text { Justice }\end{array}$ \\
\hline Communication & 0.596 & $\mathbf{0 . 7 7 2}$ & & \\
Participation & 0.686 & 0.535 & $\mathbf{0 . 8 2 8}$ & \\
Procedural Justice & 0.734 & 0.639 & 0.682 & $\mathbf{0 . 8 5 7}$ \\
\hline
\end{tabular}

\subsection{Analysis of the Constructs}

Table 3 shows the results of Collinearity and Descriptive Statistics. The means for all constructs were from 5.00 to 5.11, signifying that a majority of respondents perceived the levels of communication, participation and procedural justice range from high (5) to highest level (7) in the organization. While the values of variance inflation factor for the relationship between the independent variable (i.e. communication and participation) and the dependent variable (i.e. procedural justice) was less than 5.0, signifying that the data was not affected by serious collinearity problems (Hair et al., 2017). These results further confirm that the instrument used in this study has met the acceptable standards of validity and reliability analysis.

Table 3. The Results of Collinearity and Descriptive Statistics

\begin{tabular}{cccc}
\hline Construct & Mean & Standard Deviation & Variance Inflation Factor \\
\hline Communication & 5.11 & .81 & 1.401 \\
Participation & 5.10 & .96 & 1.401 \\
Procedural Justice & 5.00 & .93 & \\
\hline
\end{tabular}

\section{2. $\quad$ Outcomes of Testing Hypotheses 1 and 2}

Figure 1 shows that the inclusion of communication and participation in the analysis had explained 57 percent of the variance in the dependent variable. Specifically, the results of testing the research hypothesis showed two significant findings: first, communication is significantly correlated with procedural justice $(\beta=0.383 ; \mathrm{t}=3.374)$, thus $\mathrm{H} 1$ is supported. Second, participation is significantly correlated with procedural justice $(\beta=0.477 ; t=3.931)$, thus $\mathrm{H} 2$ is supported. Therefore, the result confirms that communication and participation are an important determinant of organizational commitment.

Independent Variable

(Performance based pay management)

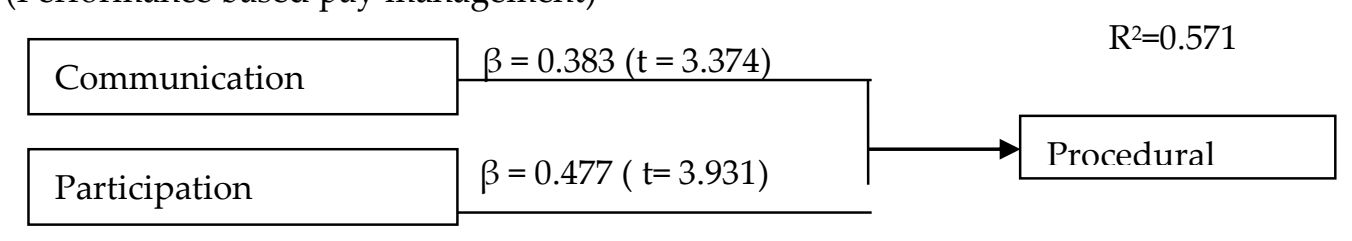


A test of predictive relevance for the reflective endogenous latent variable was further conducted based on Stone-Geisser's Formula: q2=Q2included-Q2excluded/1-Q2 included $=0.387$, indicating that it was greater than zero for the reflective endogenous latent variable. This result has predictive relevance.

\section{CONCLUSION}

The findings of this study prove that performance based pay management highly interrelated with procedural justice in the studied organizations. In the context of this study, managers focus on matters related to managers' role in managing performance based pay. Majority respondents view that the levels of communication, participation and procedural justice are high. This situation posits that the ability of managers to properly implement effective communication style and encourage employees' participation in managing performance based pay may invoke feeling of procedural justice among employees.

This study provides three important implications: theoretical contribution, robustness of research methodology and practical contribution. In terms of theoretical contribution, the findings of this study have provided great potential for understanding the effect of communication and participation in strengthening employees' feeling of procedural justice in the organization. This outcome also has supported and extended studies by (Azman et al., 2016a; Azman \& Mohd Ridwan, 2017a; Risher, 2014; Zhang et al., 2015).

With respect to the robustness of research methodology, the survey questionnaire used in this study had satisfactorily met the standards of validity and reliability analyses. This may lead to produced correct and dependable research findings.

With regards to the practical contribution, the findings of this study can be used as guidelines by practitioners to improve the effectiveness of performance based pay management. This objective can be achieve if management consider to the following aspects: first, the important elements of performance based pay management should be identified appropriately in line with the organizational objectives and strategies as well as employees' expectations. Perfection in this aspect may help employees to acquire prodigious procedural justice in their daily job and motivate them to continually support organizations' goal and strategy. Second, training content and approaches should be restructured by focusing on strengthening manager's creativity and problem solving skills. These skills will inspire managers to practice effective and efficient management style in their daily job, respect employee's needs, and share the organization interests with employees. Therefore, it may increase the capability of managers to practice comfortable pay management styles in resolving employees' grievances, demands and needs. Finally, performance based pay management should be used as an important tool to improve employees' potential and talent. For example, managers need to recognize employee needs, offer material and moral support in enhancing employees' competency, and propose the best methods to enhance employees' wellbeing in the organization. If these ideas are 
deeply considered, this may stimulate employees to increase their productivity and will enhance organizations' competitiveness in global market.

This study confirms that performance based pay management (i.e., communication and participation) has an impact on procedural justice. This finding has also strengthened and widened performance based pay management research literature, mostly published in western. Consequently, existing research and practice within performance based pay model needs to consider communication and participation as an important elements in performance based pay management domain. This study further proposes that the capability of managers to manage employees' pay perfectly will strongly induce positive employee outcomes (e.g., productivity, performance, job satisfaction and commitment). Further, these positive outcomes may lead to maintain and supported organizational competitiveness in a global economy era.

\section{ACKNOWLEDGEMENT}

We would like to thank the courier service companies for supporting this study.

\section{REFERENCES}

Aimi, A., Azman, I., \& Fatmawati, A. (2014). Administrator's role in performance pay system as a determinant of job. Sains Humanika, 2(2), 11-17.

Auh, S., \& Menguc, B. (2013). Knowledge sharing behaviors of industrial salespeople: An integration of economic, social psychological, and sociological perspectives. European Journal of Marketing, 47(8), 13331355. http://doi.org/10.1108/03090561311324354

Azman, I., Asilah, K. M. N., \& Rahmad, R. M. (2016a). Relationship between performance appraisal communication, procedural justice and job satisfaction. Malaysian Journal of Society and Space, 12(2), 15-26.

Azman, I., Fuad, Z. M., \& Aimi, A. (2015). Administrator's role in performance based reward as a determinant of employee outcomes. Management $\mathcal{E}$ Marketing Journal, 13(1), 92-110. Retrieved from http://www.mnmk.ro/documents/2015_X1/8-7-1-15.pdf.

Azman, I., \& Mohd Ridwan, A. R. (2016). Performance-based reward administration as an antecedent of job satisfaction: A case study of Malaysia' s fire and rescue agencies, 7(7), 107-118.

Azman, I., \& Mohd Ridwan, A. R. (2017a). Managers' roles in performance based reward enhancing employees' feelings of procedural justice. KINERJA, 21(2), 145-158.

Azman, I., \& Mohd Ridwan, A. R. (2017b). Performance-based reward administration enhancing employees' feelings of interactional justice. Studies in Business and Economics, 12(1), 5-18. http://doi.org/10.1515/sbe2017-0001

Azman, I., Ridwan, A. R. M., \& Zalina, I. (2016b). Sub theme: Human resource management performance based pay management as a determinant of sub theme: of extrinsic and intrinsic job, 104-114.

Barclay, D., Higgins, C., \& Thompson, R. (1995). The partial least squares (PLS) approach to causal modeling: Personal computer adoption and use as an illustration. Technology Study, 2(2), 285-309.

Biddle, B. J. (1986). Recent developments in role theory. Annual Review of Sociology, 12(1), 67-92.

Brebels, L., Cremer, D. De, \& Dijke, M. Van. (2016). Using self-definition to predict the influence of procedural justice on organizational- , interpersonal- , and job / task-oriented citizenship behavior, 40(3), 731-763. http://doi.org/10.1177/0149206311410605

Cresswell, J. W. (1998). Qualitative Inquiry and Research Design: Choosing Among Five Traditions. London: SAGE publications.

Dar, Z., \& Raja, N. S. (2014). Empirical study on the role of Procedural Justice in Performance appraisal on Turnover Intentions Mediating role of Organizational Politics, 16(1), 141-145. 
Fornell, C., \& Larcker, D. F. (1981). Evaluating structural equation models with unobservable variables and measurement error. Journal of Marketing Research, XVIII(39-50).

Geisser, S. (1975). The predictive sample reuse method with applications. Journal of the American Statistical Association, 70(350), 320-328.

Graen, G. B., \& Uhl-Bein, M. (1995). Relationship-based approach to leadership: Development of leadermember exchange (LMX) theory of leadership over 25 years: Applying a multi-level multi-domain perspective. The Leadership Quarterly, 6(2), 219-247.

Hair Jr., J. F., Hult, G. T. M., Ringle, C. M., \& Sarstedt, M. (2017). A Primer on Partial Least Squares Structural Equation Modeling (PLS-SEM) (2nd Ed.). United States of America: SAGE publications Inc.

Heffernan, M., \& Dundon, T. (2016). Cross-level effects of high-performance work systems (HPWS) and employee well-being: the mediating effect of organisational justice. Human Resource Management Journal, 26(2), 211-231.

Henseler, J. (2012). Why generalized structured component analysis is not universally preferable to structural equation modeling. Journal of the Academy of Marketing Science, 40(3), 402-413. http://doi.org/10.1007/s11747-011-0298-6

Henseler, J., \& Chin, W. (2010). A comparison of approaches for the analysis of interaction effects between latent variables using partial least squares path modeling. Structural Equation Modeling: A Multidisciplinary Journal, 17(1), 82-109. http://doi.org/10.1080/10705510903439003

Henseler, J., Ringle, C. M., \& Sarstedt, M. (2014). A new criterion for assessing discriminant validity in variancebased structural equation modeling. Journal of the Academy of Marketing Science, 43(1), 115-135. http://doi.org/10.1007/s11747-014-0403-8

Ismail, A., Mohamed, H. A.-B., Sahol Hamid, N., Zaidi Sulaiman, A., Girardi, A., \& Bin Abdullah, M. M. (2011). Relationship between performance based pay, interactional justice and job satisfaction: a mediating model approach. International Journal of Business and Management, 6(11), 170-181. http://doi.org/10.5539/ijbm.v6n11p170

Ismail, A., Rahman, H. A., \& Ismail, W. K. W. (2007). Moderating effect of procedural justice in the relationship between participation in pay systems and personal outcomes. Jurnal Kemanusiaan, 9, 83-96.

Martocchio, J. J. (2016). Strategic compensation: A human resource management approach (8th ed.). Boston, US: Pearson Education Limited.

Milkovich, G., Newman, J., \& Gerhart, B. (2014). Compensation (4th ed.). New York: McGraw-Hill International.

Newman, J. M., Gerhart, B., \& Milkovich, G. T. (2017). Compensation (12th ed.). McGraw-Hill International.

Nunnally, J. c., \& Bernstein, I. H. (1994). Psychological theory. New York: MacGraw-Hill.

Osterloh, M. (2014). Viewpoint: why variable pay-for-performance in healthcare can backfire: Evidence from psychological economics. Evidence-Based HRM: A Global Forum for Empirical Scholarship, 2(1), 120-123. http://doi.org/10.1108/EBHRM-12-2013-0037

Proost, K. (2015). Organizational justice as buffer against stressful job demands. http://doi.org/10.1108/JMP-022013-0040

Ringle, C. M., Sarstedt, M., \& Straub, D. (2012). A critical look at the use of PLS-SEM in MIS Quarterly. MIS Quarterly (MISQ), 36(1), iii-xiv. http://doi.org/10.3200/JOEB.79.4.213-216

Risher, H. (2014). Reward management depends increasingly on procedural justice. Compensation $\mathcal{E}$ Benefits Review, 46(3), 135-138. http://doi.org/10.1177/0886368714553775

Rozila, A., \& Scott, N. (2015). Fringe benefits and organisational commitment: the case of Langkawi hotels. Tourism Review, 70(1), 13-23. http://doi.org/10.1108/TR-11-2013-0065

Salim, S. S., \& Ismail, A. (2015). Adequacy of pay structure and its impact on personal outcomes. Economica, 11(6), 34-49.

Sekaran, U., \& Bougie, R. (2010). Research Methods for Business: A Skill Building Approach. New York: John Wiley \& Sons, Inc.

Shaed, M. M., Ishak, S., \& Ramli, Z. (2015). Employee s ' Participation in Decision Making (PDM): A literature survey, 13(13), 142-155.

Singh, P. S. P., \& Rana, S. (2015). The Impact of Performance Appraisal on Organizational Commitment of Bank Employees, 4(4), 2964-2967. 
Stone, M. (1974). Cross-validatory choice and assessment of statistical predictions. Journal of the Royal Statistical Society, 36(2), 111-147.

Takao, K., \& Naomi Kodaman. (2015). Performance-related Pay and Productivity: Evidence from Japan (15-E-088). Japan.

Tremblay, M., \& Landreville, P. (2015). Information Sharing and Citizenship Behaviors: Mediating the Roles of Empowerment, Procedural Justice, and Perceived Organizational Support. http://doi.org/10.1177/2329488414525459

Wahibur, R., \& Arif, H. (2012). Transformational leadership and work Outcomes: organizational justice as mediator. World Review of Business Research, 2(4), 164-171.

Webb, J., Courtney, D., Stefanie, L. H., Laura, K. J., Webb, J., Courtney, D., ... Barron, L. G. (2014). Organizational rewards: considering employee need in allocation. http://doi.org/10.1108/PR-09-2012-0156

Zhang, G., Lee, G., \& Zou, X. (2010). The mediating role of procedural justice between participation in decisionmaking and organizational citizenship behavior: An empirical study about Skeleton government civilian in China. Psychology, 1(4), 300-304. http://doi.org/10.4236/psych.2010.14039

Zhang, Y., Long, L., \& Zhang, J. (2015). Pay for performance and employee creativity: The importance of procedural justice and willingness to take risks. Management Decision, 53(7), 1378-1397. http://doi.org/10.1108/MD-11-2013-0596

Zou, L., Zhang, J., \& Liu, W. (2015). Perceived justice and creativity in crowdsourcing communities: Empirical evidence from China. Social Science Information, 1-27. http://doi.org/10.1177/0539018415583382 